\title{
Einstein the statesman
}

\section{Nancy Thorndike Greenspan enjoys a study of the physicist as engaged public figure.}

A lbert Einstein's dreams have been analysed, his love life scrutinized, his letters parsed. His brain has been dissected and driven 5,000 kilometres across the United States. In a way, he has survived it all.

In Einstein and Twentieth-Century Politics, it is the physicist's politics and principles that are once again debated. Einstein is the global thinker, a scientist with important social insights and a charismatic personality besides. Richard Crockatt shows that the causes that he championed embody the world's conflicts of the time: pacifism; zionism and Israel; the atomic bomb and the arms race; and world government. Writes Crockatt (a British scholar of US foreign policy and mid-twentieth-century international relations): "In looking at his life and ideas one sees over his shoulder into the world he lived in, not merely into his mind."

Einstein's first public foray into politics was in 1914. He was bold from the start: aged 35 and teaching at the University of Berlin, he was one of only four signatories to a manifesto against the First World War. It was to counter another signed by 93 of his peers, defending Germany's 'just' war. He didn't state so openly, but Einstein hoped that Imperial Germany would lose the war and rise from the ashes as a democratic socialist government.

Before the war, he was little-known outside physics. Celebrity enveloped him in 1919, when experimentalist Arthur Eddington confirmed the general theory of relativity. After this, Einstein - who was Jewish - was no longer a mere mortal, a fact that roused an increasingly antiSemitic Germany. Anti-relativists with an anti-Jewish agenda attacked him. In this and only this instance, he lashed out in a newspaper article, which brought more attacks. He learned that detractors could agitate him, that he needed to protect his privacy and that entering the political fray disrupted his science. From then on, he made pronouncements on political and moral issues that aimed to keep him above ordinary politics. These dimensions are all nimbly woven into Einstein and Twentieth-Century Politics.

After the First World War, the League of Nations was founded to advance peace. Einstein had an ambivalent relationship with it, as did many of his liberal contemporaries. They feared that the military strength of nations would thwart their pacifist goal. The devastation of the war had made many a pacifist purist. But in 1933, having left Germany

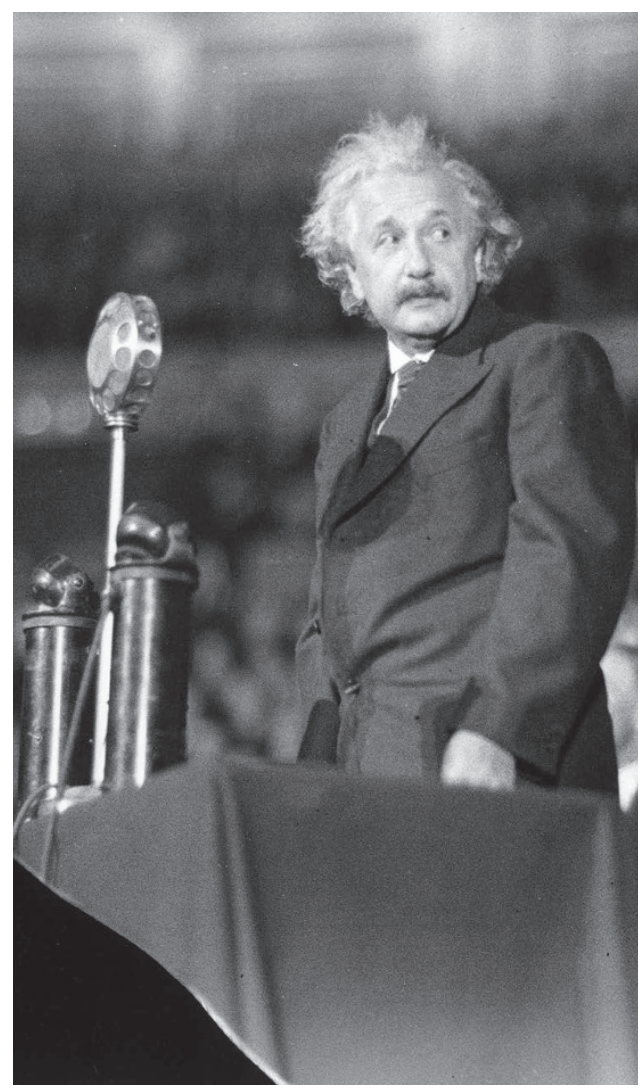

Einstein speaking on science and civilization in 1933.

for the United States in the face of the Nazi assault, Einstein refined his views. A grudging pragmatism took hold: what good would come from supporting peace if freedom were lost? Allied military strength became a benefit. Such was his evolution on many issues, garnering criticism in private from his leftist intellectual friends and in public from his foes, especially those in the US government. He was characterized variously as reckless, hypocritical, naive and pro-Soviet.

One decision promoting the building of the atomic bomb - he regretted until he died. He wrote three letters to US President Franklin Roosevelt: the first two advocated for the bomb; the last indirectly warned against using it. After the Second World War, he explained his rationale
Einstein and

TwentiethCentury Politics: "A Salutary Moral Influence" RICHARD CROCKATT Oxford University Press: 2016.
- and that he never worked on the bomb but he could not break the public's perception that he was responsible for it. In the end, all he could do was to press more urgently for a supranational government that controlled military power, especially the bomb.

Crockatt skilfully uses letters and articles from "the liberal wing of international opinion", non-scientists all, to limn the subtleties of the issues. Philosophers Bertrand Russell and Albert Schweitzer; writers George Bernard Shaw, Thomas Mann and H. G. Wells; and Mahatma Gandhi - with a cameo by Sigmund Freud - all draw out the nuances in Einstein's positions and expose the complexities created by a rapidly changing world. They agreed, more or less, on the objective: a world government that limits the power of the nation-state and nullifies war. Details, such as the role of the state, create the debate.

Crockatt's deft pen and thoughtful approach form an engaging and revealing image of Einstein the non-scientist. He marshals a wealth of material into a convincing narrative. However, to tease out Einstein's "distinctive intellectual and emotional qualities", Crockatt may have overreached. In essence, he alleges that Einstein examined every angle of a scientific idea but "rarely, if ever, questioned" his political principles because they were self-evident.

I doubt it was that black and white. Crockatt himself describes numerous incidents in which Einstein altered his political positions fundamentally. Crockatt suggests that the shifts were tactical, but they must have required deep reflection and questioning. These were profoundly consequential decisions. Nor was Einstein entirely the dispassionate, empirical scientist of his own characterization or that Crockatt assumes. Einstein's argument for rejecting quantum mechanics, that God "does not play dice", was more about intuition than well-founded scientific principle.

Nevertheless, Einstein and TwentiethCentury Politics delivers what Crockatt promises: a picture of Einstein's world and mind, conveyed with an insightful brush. And these issues political and philosophical are sufficiently complex that they will surely live to see many other interpretations.
Nancy Thorndike Greenspan is a writer based in Washington DC. Her most recent book is The End of the Certain World: The Life and Science of Max Born. e-mail:nancy@nancygreenspan.com 